\title{
Fluvial contributions of nutrient salts, dissolved trace elements and organic carbon to the sea by pristine temperate rivers (SW Europe)
}

\author{
P. Bernárdez, ${ }^{A, B, D}$ N. Ospina-Alvarez, ${ }^{A} M$. Caetano ${ }^{C}$ and R. Prego ${ }^{A}$

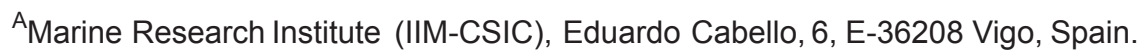 \\ ${ }^{B}$ Marine Geosciencies Department, University of Vigo, Fonte das Abilleiras s/n, E-36310 Vigo, Spain. \\ ${ }^{C}$ Instituto Português do Mar e da Atmosfera (IPMA), Division of Environmental Oceanography and Bioprosepction, \\ Avenida Brasília 6, PT-1449-006 Lisbon, Portugal. \\ DCorresponding author. Email: pbernardez@uvigo.es
}

\begin{abstract}
Environmental context. We report the baseline levels of dissolved nutrients, organic matter and metals in the main temperate rivers draining the three Northern Galicia rias. Because the rivers are pristine, these rias are little affected by anthropogenic inputs, and their properties reflect the lithological characteristics of the rivers' watersheds. Useful information in the development of European and global initiatives for assessing anthropogenic inputs to estuarine, coastal and open-sea environments has been provided.
\end{abstract}

\begin{abstract}
A summary of the water characteristics of the rivers Sor, Mera and Landro that drain into the Northern Galician Rias (NW Iberian Peninsula) is presented. The analysis was based on fortnightly monitoring during 2008, for major and minor chemical elements in the dissolved phase (Al, As, Cd, $\mathrm{Co}, \mathrm{Cu}, \mathrm{Fe}, \mathrm{Mn}, \mathrm{Mo}, \mathrm{Ni}, \mathrm{Pb}, \mathrm{U}, \mathrm{V}, \mathrm{Zn}$ ), nutrients (nitrate, nitrite, ammonium, phosphate, silicate), suspended particulate matter, chlorophyll-a and tracers of water quality chemistry (dissolved inorganic nitrogen and carbon). The data cover rivers not urban, agriculturally or industrially affected. Continental inputs of the material via rivers into the Northern Galician Rias were measured and annual fluxes of the dissolved chemical elements to the rias were calculated. In spite of the high variability in water flow, this study provides a good estimate of the overall amounts of nutrients and dissolved elements discharged to pristine ria systems.
\end{abstract}

Additional keywords: DOC, Northern Galician Rias, NW Iberian Peninsula.

\section{Introduction}

River discharges are one of the sources of dissolved chemical elements for estuaries and rias, coastal waters and offshore waters. To date there are reliable published data on trace metal levels and element concentrations in the dissolved phase for freshwater systems. Concentrations of dissolved elements, organic material and inorganic nutrients found in rivers are derived from a variety of anthropogenic $^{[1-3]}$ and natural sources. ${ }^{[4-8]}$ Although fluvial transport is a major mechanism for removal of metals and nutrients from continental land masses to coastal areas, shelves and open oceans, little information is available regarding how trace-metal concentrations vary with fluvial characteristics such as discharge and suspended-sediment concentration. ${ }^{[9]}$ Moreover, little information is available on how the characteristics of landmasses covering the river basins influence the composition of river waters in the dissolved phase, especially in pristine regions. As such, a knowledge of dissolved metal concentrations, dissolved organic carbon (DOC), chlorophyll-a (Chl-a) and nutrients content and transport mechanisms is needed to characterize chemical elements cycling and bioavailability in receiving waters, such as the Galician Rias.

The quantification of the land-based fluxes of different chemical constituents is a key factor to ascertain how those budgets can affect natural biogeochemical processes and fertilisation, and to detect ecotoxicological risks in coastal systems. This is especially critical for those coastal areas where the riverine or land-based inputs are discharged into enclosed embayments, such as the Galician Rias. The quantification of fluxes, including contaminants, organic material and nutrients, between land and sea at a regional and a global scale is important. There is a lack of the knowledge of these fluxes in pristine European rivers, because these data are patchy for each river. Only the works of Martin and Meybeck, ${ }^{[10]}$ Meybeck and Helmer ${ }^{[4]}$ and Gaillardet et al. ${ }^{[8]}$ present a global database of concentrations and fluxes of dissolved trace elements in rivers. Water quality in European rivers is far from favourable; most of the data is focussed on large rivers with high drainage basins and are strongly affected by pollution. However, no work on small European rivers from non-industrialised and non-human affected areas has been undertaken to determine their natural background state. There is only limited data on metals, 
DOC, Chl-a and nutrients analysis and river water quality in freshwater systems for dissolved species ${ }^{[8,11-14]}$ as well as hydrologic parameters. ${ }^{[15-18]}$ The characteristics of the dissolved elements transported by the river flow and budgets of this organic and inorganic material draining into the Galician rias are very restricted, ${ }^{[19-23]}$ and this lack of information is one of the reasons of this research.

This paper investigates the characteristics of three natural rivers (Sor, Mera and Landro Rivers, NW Iberian Peninsula) draining into the Northern Galician Rias, in terms of river discharges and hydrochemical and biological conditions, across an annual cycle. The principal goal of this study is to characterise and establish baseline levels for chemical elements in the dissolved phase (Al, As, Cd, Co, $\mathrm{Cu}, \mathrm{Fe}, \mathrm{Mn}, \mathrm{Mo}, \mathrm{Ni}, \mathrm{Pb}, \mathrm{U}, \mathrm{V}, \mathrm{Zn}$, organic carbon, inorganic nitrogen, silicate, phosphate) in the riverine waters flowing into the northern rias of Galicia. It is also an aim of this study to quantify their annual fluxes to the Northern Galician Rias.

\section{Material and methods}

\section{Study site}

The Northern Galician Rias (locally named Northern Rias or Rias Altas) ${ }^{[24,25]}$ are located eastward of 88W (Cape Ortegal), approximately along the $43.68 \mathrm{~N}$ parallel (Fig. 1). The Ortigueira (38- $\mathrm{km}^{2}$ surface area), Barqueiro $\left(10 \mathrm{~km}^{2}\right)$ and Viveiro $\left(27 \mathrm{~km}{ }^{2}\right)$ Rias form part of the northern rias of Galicia. They form narrow wedge-shaped marine inlets along former fluvial valleys that display a wide outer marine zone. They are dominated by marine processes except at the inner estuarine (mesotidal) zone which is partially enclosed with well developed beach barriers (see Alvarez et al. ${ }^{[26]}$ for a complete description). In this area, the climate is wet temperate oceanic (Cfb Kö ppen type). The annual average air temperature (data from 'Penedo do Galo' Station, Meteogalicia) during the sampling year 2008 was $10.4^{\circ} \mathrm{C}$, with a thermal fluctuation of $8^{\circ} \mathrm{C}$ and an average humidity of $79.6 \%$. Daily global irradiation was on average $11120 \mathrm{~kJ} \mathrm{~m}^{-2}$. Mean rainfall in 2008 was $4.33 \mathrm{~L} \mathrm{~m}^{-2}$ with a total of 168 days of rain. Westerly winds in autumn-winter characterised the wind regime in this zone, whereas in spring and summer easterly winds prevail. Nevertheless, easterly winds can be also observed in autumn winter. ${ }^{[27]}$

The rivers draining into the Northern Galician Rias are an example of a natural system with reduced anthropogenic impact. They flow along pine and eucalyptus forests and scrublands with only a small proportion of cultivated areas on the floodplain. The population density is low (,70 inhabitants $\mathrm{km}^{-2}$ ) and concentrated mostly near the river mouth. The Mera River, situated at the head of the Ria of Ortigueira (basin area: $\left.127 \mathrm{~km}^{2}\right)$ is the main fluvial source flowing into the ria, although small tributaries such as the Baleo $\left(53 \mathrm{~km}^{2}\right)$, Landoi $(21$ $\mathrm{km}^{2}$ ) and Lourido $\left(10 \mathrm{~km}^{2}\right.$ ) Streams also drain into the ria. The Mera annual average flow is $6.0 \mathrm{~m}^{3} \mathrm{~s}^{-1}$ (Station $443^{[28]}$ ). The larger Mera River flows through extensive pine and eucalyptus forests, and forms a very shallow estuary containing extensive marshlands. The Mera River flows along a varied lithology of metamorphic rocks, e.g. gneiss, slates, quartzites and schists (Fig. 1). The distinct feature of the Mera River chatchment is the presence of mafic and ultramafic rocks with few zones of serpentinised peridotites and ecoglites located upstream (Fig. 1). The permeability of the river basin is very low. ${ }^{[15]}$ The Sor River drains into the Ria of Barqueiro, located west of Cape Estaca de Bares $\left(43847^{\circ} \mathrm{N}, 7841^{\circ} \mathrm{W}\right)$. The fluvial basin of the Sor River covers $202 \mathrm{~km}^{2}$ with an annual mean discharge of $15.2 \mathrm{~m}^{3} \mathrm{~s}^{-1}$ (Station $440^{[28]}$ ). Land use in the Sor River basin is mainly scrubland and pine and eucalyptus forest. The Sor River basin is covered by metamorphic rocks such as gneisses slates and quartzites. The catchment is also made up of two-mica granite and the presence of NWN-oriented white quartz veins (Fig. 1). The Landro River is located at the mouth of the Ria of Viveiro, and covers an area of $271 \mathrm{~km}^{2}$. It has a mean discharge of $9.3 \mathrm{~m}^{3} \mathrm{~s}^{-1}$ (Station $438^{[28]}$ ), with an estuary in the inner part of the inlet, with extensive marshlands and a beach barrier. The basin of the Landro River covers a mixed area of metamorphic rocks (gneisses and metasediments) and granitic alcaline rocks being part of the Manto de Mondoñedo Domain (Fig. 1).

\section{Sampling and survey program: sample treatment and analytical methods}

Hydrological and hydrochemical sampling of the three largest rivers: Sor, Mera and Landro draining into the Northern Galician Rias was carried out fortnightly during 2008. Daily river flow data of the main rivers running into the three Northern Galician Rias were supplied by the Aguas de Galicia Co. dependent on the 'Consellería de Medio Ambiente' of the Xunta de Galicia. The river flow for each river was obtained during the sampling period from a scale in a gauging station out of the tidal influence managed by Augas de Galicia. In the Mera River the station is called 443 (Santa Maria de Mera,43.648N, 7.908W, gauged area $102.2 \mathrm{~km}^{2}$ ). Station 440 is named for the Sor River (Puente Segade, 42.828N, 7.758W, gauged area $66.5 \mathrm{~km}^{2}$ ). For the Landro River, the gauging station is called Station 438 (Chavín, 43.618N, 7.588W, gauged area $198 \mathrm{~km}^{2}$ ). Daily flows were area corrected considering the whole river basin area: 127, 202 and $270 \mathrm{~km}^{2}$ for the Mera, Sor and Landro Rivers. The relatively low-gauged area for the Sor River could lead to an overestimation of the river flow during high precipitation events. However, flood episodes are of low duration and occurred rarely during the sampling period, and therefore, overestimation is negligible.

Air temperature $\left({ }^{\circ} \mathrm{C}\right)$ and daily rainfall $\left(\mathrm{L} \mathrm{m}^{-2}\right)$ were obtained from the meteorological station Penedo do Galo located at $43.668 \mathrm{~N}$ and $7.568 \mathrm{~W}$ and supplied by the Regional Weather Forecast Agency (METEOGALICIA). Salinity was measured using a WTW MultiLine F/Set-3 (error range: \pm 0.1 ).

Dissolved oxygen concentrations were measured by Winkler titration of samples using an automatic titrator (702-SM Titrino, Metrohm) to calculate saturation percentages, ${ }^{[29]}$ with an error range of \pm 0.2 . Samples were fixed and analysed within $24 \mathrm{~h}$. Nutrient salt samples (nitrate, nitrite, ammonium and phosphate) were collected in $50-\mathrm{mL}$ plastic bottles and immediately frozen at $-20^{\circ} \mathrm{C}$. As orthosilicate polymerisation may occur in freshwater frozen samples, ${ }^{[30]}$ rivers were also sampled using 10 -mL plastic bottles and preserved at 4 ${ }^{\circ} \mathrm{C}$ and dissolved silicate was analysed the next day. Nutrient salts were analysed in the laboratory using an Integral Futura autoanalyzer 
system (Alliance Instruments) with separate lines for nitrate, nitrite, ammonium, phosphate and silicate according to standard colourimetric methods. $^{[31]}$

Samples for Chl-a analysis were also taken and processed as for the seawater samples. Samples were immediately filtered on to a Whatman GF/F filter (25-mm diameter) and the Chl-a concentration was determinate by spectrofluorimetry ${ }^{[32]}$ after extraction with $90 \%$ acetone according to the literature method ${ }^{[33]}$ DOC was determined using a Shimadzu TOC-VCSH analyser by high temperature catalytic oxidation (HTCO), following the procedure described by Álvarez-Salgado and Miller. ${ }^{[34]}$ DOC analyses were accredited by ENAC according to UNE-EN ISO/IEC 17025:2005.

Concentrations of $\mathrm{Al}, \mathrm{As}, \mathrm{Cd} \mathrm{Co}, \mathrm{Cu}, \mathrm{Mn}, \mathrm{Mo}, \mathrm{Ni}, \mathrm{Pb}, \mathrm{V}$ and $\mathrm{U}$ were determined in the dissolved phase from the Sor, Mera and Landro Rivers, based on biweekly sampling. Low density poly(ethylene) 1000-mL bottles were previously acid washed for a week, rinsed with Milli-Q50 water, filled with Milli-Q50 water acidified to $\mathrm{pH} 2$ and stored in zip-lock plastic bags. At an onshore clean portable laboratory, samples were separated into dissolved and particulate components by filtration through a 0.45 -mm polycarbonate filter in a laminar flow cabinet, within $4 \mathrm{~h}$ of collection. ${ }^{[35]}$ In this way, suspended particulate matter was calculated $\left(\mathrm{SPM}\right.$, mg $\left.\mathrm{L}^{-1}\right)$. The filtration was carried out using $0.45-\mathrm{mm}$ filter circles and this was used to operationally define the separation between dissolved and particulate components. ${ }^{[35,36]}$ Note that this filtration is operationally defined ${ }^{[37]}$ and that the dissolved phase can include microparticulate material ${ }^{[38]}$ such as colloids and nanoparticles. Handling and analysis of samples were carried out in a clean laboratory (ISO class 7-8). All plastic labware used for sampling, storage and sample treatment was acid cleaned $\left(\mathrm{HNO}_{3}, 10 \%\right)$ for at least $48 \mathrm{~h}$ and washed throughout with Milli-Q50 water. Chemical elements in the dissolved phase were determined by inductively coupled plasma-mass spectrometry (ICP-MS, Thermo-Elemental X-Series) ${ }^{[39]}$ at the laboratory of the Department of Aquatic Environment (IPIMAR, Lisbon). Procedural blanks accounted for less than $1 \%$ of element concentrations in the samples. The precision and accuracy of the analytical procedures was determinated using SLRS-4 certified reference material (Table 1).

\section{Calculation of fluxes}

Chemical fluxes of dissolved elements in the rivers draining into the Northern Galician Rias were estimated from daily discharge and element concentrations. In theory, the total flux over a given period of time is the integration of instantaneous fluxes, which would require continuous determination of discharge and trace element concentrations. ${ }^{[40]}$ Moreover, the quantification of the annual contribution of the chemical species from each source could be based on the annual average flow and the annual average concentration of each element, but this only produces an estimate because in most cases the material flux is not linear in relation to the flow. However, as several chemical species concentrations can hardly be measured continuously, element flux estimates presented in this paper are based upon adapted algorithms recommended by Meybeck et al. ${ }^{[41]}$ In that way, the transport of dissolved substances and metals in the Sor, Mera and Landro Rivers has been estimated by means of the classical way of calculating the chemical discharge from the river flow and concentration relationship. Here we use the exponential CQ (concentration-flow) equation employed by Meybeck et al., ${ }^{[41]}$ which has been used extensively. ${ }^{[42-45]}$ This relationship is applied to the high frequency discharge record in order to generate a high frequency concentration time series. This series can be combined with the discharge series to calculate the total load over the required period of time ${ }^{[42]}$ because flow and load were assumed to be described by a bivariate log-normal distribution. ${ }^{[46]}$

$$
F=\sum_{i=1}^{i=n} Q_{i} C_{i}
$$

where $Q_{i}$ is the daily flow (data from Aguas de Galicia) and $C_{i}$ is the daily concentration of the chemical substance or metal obtained from Eqn 2:

$$
C_{i}=a Q_{i}{ }^{b}
$$

Annual fluxes $\left({\mathrm{kg} y e a r^{-1}}^{-1}\right.$ or year $\left.{ }^{-1}\right)$ were calculated as the sum of daily fluxes over the entire year.

Fortnightly sampling during a 1-year period was carried out, and the CQ equations obtained were considered appropriate

when the critical value of the correlation coefficient ( $r$ in Table 2) was higher than 0.472 (1-tailed testing of 0.01 to $n 1 / 4$ 24). Mean annual flux was also estimated and was based on an average of the fluxes over the year (Table 3 ). When

$r, 0.472$ (Table 2) the flux (F) was approximately estimated by multiplying the annual average flow of the river by the average concentration of each element or substance.

$$
F=\overline{Q C}
$$


Comparing data using Eqn 1 or 3 for $r .0 .472$ results in a difference in QC of $1.4 \pm 0.6$ times higher than from average values. Periods of high discharge ( 5 times higher than the mean annual value) are short in duration and they do not have a high significant influence on estimated fluxes.

\section{Results and discussion}

\section{Hydrological and meteorological conditions}

During 2008, daily variations in the discharge flux are closely related to variation in precipitation (Fig. 2). This close coupling between discharge and rainfall results from the high impermeability of the catchment area. ${ }^{[15]}$ Consequently, the sampling stations reflect variations in the precipitation. The discharge of these rivers is related to the natural hydrology of the whole drainage basins (e.g. wet or dry years, local events of high discharge), and as a consequence, fluxes of water and SPM show high temporal variability. The air temperature during 2008 was also low $\left(10.1^{\circ} \mathrm{C}\right)$ compared to a 'normal' year $\left(14^{\circ} \mathrm{C}\right)$ (Fig. 2$)$.

At the Northern Galician Rias, the drainage basins received abundant rain during 2008 (annual 2008 average, $2.97 \mathrm{~L} \mathrm{~m}^{-2}$ ) with low duration peaks of $61 \mathrm{~L} \mathrm{~m}^{-2}$, which produces a large flow per basin area. The drainage index for the studied rivers ${ }^{[15]}$ indicates that the rainfall constitutes most of the water supply to these small rivers driving the variations in river flow (Fig. 2). In this way, the mean annual river flow variation in the Sor River during 2008 was $19.3 \mathrm{~m}^{3} \mathrm{~s}^{-1}$, with a maximum value of $205 \mathrm{~m}^{3} \mathrm{~s}^{-1}$ and a minimum of $4.3 \mathrm{~m}^{3}$ $\mathrm{s}^{-1}$. This average value was higher than the mean value obtained over several years (mean 1996-2010: 15.2 $\mathrm{m}^{3} \mathrm{~s}^{-1[28]}$ ). The opposite occurred in the Mera River, with mean values of $5.97 \mathrm{~m}^{3} \mathrm{~s}^{-1}$ during 2008, whereas the average value was $6.0 \mathrm{~m}^{3} \mathrm{~s}^{-1}$ (mean 1970-2010, Augas de Galicia ${ }^{[28]}$ ). This was also observed in the Landro River, the mean flow of which during 2008 was $10.1 \mathrm{~m}^{3} \mathrm{~s}^{-1}$ in contrast with $9.3 \mathrm{~m}^{3} \mathrm{~s}^{-1}$ as a general average (mean 1975-2010 $0^{[28]}$ ).

\section{Key variables}

The mean water temperature was $13.8^{\circ} \mathrm{C}$ during 2008 for the Sor River, whereas in the Mera River the average water temperature was $13.1{ }^{\circ} \mathrm{C}$, and in the Landro River $12.8^{\circ} \mathrm{C}$. In the case of salinity, the values are consistently below $1 \%$ of salinity, which indicates a freshwater input and no tidal influence in the sampling stations. The $\mathrm{pH}$ for most of the rivers was neutral, with low variations, showing similar values to those found for the nearby rivers draining into the Ria of Vigo ${ }^{[21,22]}$ and for world global pristine rivers draining granite and gneiss rock type ${ }^{[4]}$ as shown in Fig. 1. The Mera River has an average $\mathrm{pH}$ value of 7.28 and a maximum value of 7.85. Oxygenation in these rivers is always high with mean values near to saturation (93-103\%; Fig. 3). These values are common in the Galician Rias, as has been reported in previous papers. ${ }^{[20,21,23]} \mathrm{SPM}$ was recorded in mean abundances ranging from $0.87 \mathrm{mg} \mathrm{L}^{-1}$ in the Sor River, $2.23 \mathrm{mg} \mathrm{L}^{-1}$ in the Mera River and $2.85 \mathrm{mg} \mathrm{L}^{-1}$ for the Landro River (Fig. 3). Variations in particulate matter are noticeable in the Landro River, because values reach up to $8.2 \mathrm{mg} \mathrm{L}^{-1}$. Similar values have been reported by other authors $\left(0.33-18.70 \mathrm{mg} \mathrm{L}^{-1}\right)$ in the rivers flowing into the Ria of Vigo ${ }^{[23,47]}$ and, in other Galician Rias such as the Ferrol, values for rivers of $15-20 \mathrm{mg} \mathrm{L}^{-1[20]}$ have been obtained. The Chl-a abundance was similar for the Mera and Landro Rivers $\left(0.50\right.$ and $\left.0.48 \mathrm{mg} \mathrm{L}^{-1}\right)$ and lower for the Sor $(0.29 \mathrm{mg}$ $\mathrm{L}^{-1}$ ) (Fig. 3). In all cases, the Chl-a concentration was low because nitrate effluents or phosphate does not enhance primary production. Chl-a concentrations correlated well with SPM as observed in other riverine systems. ${ }^{[4]}$ The residence time of water in the rivers was low and thus primary production was limited and controlled by non-saturated nutrients.

\section{Characterisation of dissolved material}

The extension, characteristics and topography of the drainage basin, the rainfall regime, together with the lithology features (Fig. 1) and the different land uses (forest, agriculture, industry, urban settlements, occurrence of peat bogs, wetlands and marshes), determines the inorganic and organic loads of a river stream. ${ }^{[4,49]}$ Moreover, characteristics of the dissolved material contained in river waters are highly variable due to environmental conditions such as basin lithology, the weathering of surface rocks, land use, vegetation and the degradation of terrestrial organic matter and climate. ${ }^{[4]}$ However, a vast majority of dissolved elements and species in natural waters are closely associated with rock weathering, climate characteristics, land use and vegetation, together with other sources such as atmospheric or anthropogenic contributions. ${ }^{[8]}$

Nutrient concentrations in the three rivers studied were similar for nitrate, nitrite and ammonium (Fig. 4). Nitrate accounted for more than $95 \%$ of the dissolved inorganic nitrogen (DIN). This is in contrast to the Oitaben River system (Ria of Vigo) where nitrate represented $80 \%$ of DIN. ${ }^{[21]}$ Nitrite and ammonium concentrations were very low for all rivers, accounting for less than $5 \%$ of DIN. Average values of 0.11 and $0.71 \mathrm{mM}$ for the Sor River, 0.16 and $1.02 \mathrm{mM}$ for the Mera River and 0.16 and $1.09 \mathrm{mM}$ for Landro River were determined for nitrite and ammonium. These features are similar to that found in Galician ${ }^{[19]}$ and Cantabrian rivers. ${ }^{[50]}$ These nitrogen compounds are primarily influenced by biological processes ${ }^{[6]}$ but also by anthropogenic inputs, rainfall and leaching of chemical species to groundwater. ${ }^{[4]}$ The concentrations determined here are in the range for values reported for Galician rivers (18$40 \mathrm{nM}^{[51,52]}$ ) suggesting no anthropogenic inputs (e.g. nitrogen fertilisers).

Phosphate concentrations were also very low, in comparison with other rivers in the same area, ${ }^{[19,21]}$ with a maximum of $0.34 \mathrm{mM}$ and an average of $0.11 \mathrm{mM}$. These values are in accordance with natural levels and suggest little influence from agricultural and urban activities in the area. Moreover, the low population density in basins draining the northern rias of Galicia avoids inputs of detergents, cleansers and industrial chemicals that are phosphate rich, ${ }^{[4]}$ maintaining the phosphate concentrations in their natural values. Phosphorous appears to be a limiting nutrient in many streams. ${ }^{[53]}$ However, average values of , $0.11 \mathrm{mM}$ in these rivers could indicate that phosphate does not limit biological production in these rivers.

Several differences between rivers were obtained in terms of silicate concentration. Silicate concentrations in the Sor River waters 
ranged from 64 to $110 \mathrm{mM}$, whereas for Mera and Landro Rivers the average values are 164.1 and $141.9 \mathrm{mM}$ (Fig. 4). These values are in the range found for rivers draining into the Galician Rias ranging from 60 to $210 \mathrm{mM} \cdot{ }^{[19,54]}$ Surprisingly, silicate concentrations in these rivers are 10 times higher than those obtained for the Oitaben River ${ }^{[21]}$ highlighting the importance of keeping the samples preserved at $4{ }^{\circ} \mathrm{C}$ instead of frozen. ${ }^{[30]}$ According to the reported data, silicate concentrations in the north of Galicia ${ }^{[51,52]}$ are, $54 \mathrm{mM}$ $\left(\mathrm{SiO}_{2}\right)$. Because biological processes might control this chemical species, its concentration varies along the studied time period. However the relation with freshwater flow is high (Table 2) indicating that hydrological features appear to control its concentration.

All studied rivers exhibit a low concentration of DOC which is typical for rivers draining mid-latitude areas. ${ }^{[8,11]}$ DOC concentrations were similar between the Sor and Mera Rivers, with respective mean values of 121.6 and 109.9 mM. The Landro River had higher DOC values, with an average concentration of $205.3 \mathrm{mM}$ (Fig. 4). DOC concentrations in rivers of the Galician region are scarce, but previously reported values, e.g. for the Oitaben River draining into the Ria of Vigo, range between 60 and $100 \mathrm{mM} .^{[21,51]}$ However, in European rivers, concentrations range between 162 and $1025 \mathrm{mM} \cdot{ }^{[8]}$ The behaviour of carbon in a dissolved organic form is highly dependent on the biological processes acting in the riverine environment as well as the sources of organic matter to these rivers. Because the river watersheds and soils are rich in organic carbon $\left(1.3-4.1 \mathrm{wt} \%{ }^{[1,52]}\right.$ ) DOC concentrations are significant, and suggest that biological processes that consume DOC (e.g. heterotrophic activity) are of minor importance. Moreover, no evidence of organic carbon point sources from fluvial wastewater have been recorded..

Dissolved $\mathrm{Al}, \mathrm{Fe}$ and $\mathrm{Mn}$ are the most abundant elements, with values ranging from 0.3 to $5.6 \mathrm{mM}$ for $\mathrm{Al}, 0.1$ to $2.5 \mathrm{mM}$ for $\mathrm{Fe}$ and 29 to $500 \mathrm{nM}$ for Mn. On average, the Landro River had a higher concentration of these three elements because the Fe and Mn exploitations found in the metamorphic rocks domain of the Landro watersheds (Fig. 1). Values of dissolved Fe were in the same range or even lower than those obtained for Galician rivers ${ }^{[22,51,52]}(528-4342 \mathrm{nM})$ and pristine rivers $\left(642 \mathrm{nM}^{[55]}\right)$, but lower than the world rivers' average $\left(1181 \mathrm{nM}^{[8]}\right)$. The natural abundance of dissolved $\mathrm{Al}$ on a global scale is $1186 \mathrm{nM},{ }^{[8]}$ indicating that the studied rivers have higher concentrations. This abundance is associated with the lithological characteristics of the river basins, enriched in Al-Si derived minerals as observed for other Galician rivers ${ }^{[51,52]} \quad(1152-3200 \mathrm{nM})$. However, the Mera River always had lower concentrations of $\mathrm{Al}$ (Fig. 4). This fact could be due to the presence of mafic and ultramafic rocks poor in Al-bearing minerals (serpentine group) in this basin (Fig. 1). Because granitic and metamorphic watersheds are more abundant in the Sor and Landro River basins, the content in $\mathrm{Al}$ increases in the dissolved phase. In the case of $\mathrm{Mn}$, concentrations in northern Galician rivers were low in comparison with the global average ${ }^{[8]}(618 \mathrm{nM})$ and with other European rivers with the same characteristics. ${ }^{[1,51,52]} \mathrm{Mn}$ and Fe are highly dependent upon the redox conditions in the system. ${ }^{[6]}$ Moreover, phytoplankton may be effective in Mn deposition ${ }^{[56]}$ provoking a decreasing concentration in the dissolved phase. In the case of the Galician rivers, $\mathrm{Fe}^{2 p}$ is the predominant form in the dissolved phase $^{[51,52]}$

In the Mera and Sor Rivers, dissolved U average values were 0.07 and $0.10 \mathrm{nM}$, which are within the range of concentrations reported in stream waters of Galicia $\left(, 0.12 \mathrm{nM}^{[51,52]}\right)$. In contrast, high concentrations of $\mathrm{U}$ have been measured in the Landro River $(0.17$ $0.75 \mathrm{nM})$. The concentration of $\mathrm{U}$ in world rivers has a global average of $1.56 \mathrm{nM}$, but these values can rise up to $20 \mathrm{nM} .^{[8,57]}$ High $\mathrm{U}$ values in subsoil $\left(.2 .88 \mathrm{mg} \mathrm{kg}^{-1}\right)$ occurred in relation with granitic rocks in Galicia and thus it can be hypothesised that in the Landro River, which has a granitic nature ${ }^{[58]}$ (two mica granite; Fig. 1), the U dissolved concentrations must be higher.

Vanadium concentrations were similar between the studied rivers, with average values ranging between 8.5 and $22.6 \mathrm{nM}$. Dissolved $\mathrm{V}$ concentrations were not reported for rivers draining into the Galician Rias, but for world rivers ranges have been reported between, 0.5 and $45 \mathrm{nM}$ depending on the lithological characteristics of the river basin catchment. ${ }^{[8,51,52,59,60]}$ The world global average concentration is $13.9 \mathrm{nM}^{[8]}$ Weathering rate and type of source rock appear to be the important factors in determining fluvial dissolved vanadium concentrations. ${ }^{[59]}$

Zinc concentrations were very similar in all rivers (average values of ,35 nM) indicating that differences in the lithological characteristics of the river basins have no influence. World background concentrations of dissolved $\mathrm{Zn}$ ranged between 7 and 153 $\mathrm{nM}^{[6,8]}$ Dissolved $\mathrm{Zn}$ concentrations were in the range of the reported Galician rivers' background, which was

estimated to be $20-49 \mathrm{nM},{ }^{[51,52,61]}$ but values found for the studied rivers were slightly higher than those found for uncontaminated rivers $\left(1.2 \mathrm{nM}^{[6,55]}\right)$.

Arsenic concentrations were low for all rivers, especially for the Landro (2.10 nM on average) and Mera (3.65 nM). In the Sor River the average concentration was slighty higher $(5.0 \mathrm{nM})$ due to the presence of As-mineralised areas in the river basin. ${ }^{[62]}$ These concentrations were much lower than those found for highly polluted rivers, ${ }^{\left[{ }^{3]}\right.}$ but in the same range as the global average $\left(8.27 \mathrm{nM}^{[8]}\right)$ and Galician rivers $\left(4.8-22.95 \mathrm{nM}^{[51,52]}\right)$.

Molybdenum concentrations were also low for all rivers ranging from 0.1 to $1.2 \mathrm{nM}$ in comparison with the natural abundance in world rivers ${ }^{[8]}$ (global average $4.37 \mathrm{nM}$ ), but they are in the same range of the values reported for some European rivers of , $0.41 \mathrm{nM}^{[11,51,52]}$ As reported for arsenic, dissolved Mo concentrations in the Mera River are slightly higher due to the presence of higher contents of this element in the soils of the river basin. ${ }^{[62]}$

For $\mathrm{Cd}$ and $\mathrm{Pb}$, no significant differences can be found between rivers. Dissolved $\mathrm{Pb}$ values for the Sor, Mera and Landro Rivers were lower than the range reported for the Galician ${ }^{[20,51,52]}$ or world rivers $\left(, 1 \mathrm{nM}^{[6]} ; 0.2 \mathrm{nM}^{[55]}\right)$. The Cd concentration in rivers of the Northern Galician Rias were also an order of magnitude higher than concentrations found for the rivers and streams in the Ria of Ferrol ${ }^{[20]}$ and Oitaben River draining into the Ria of Vigo $\left(0.03 \mathrm{nM}^{[61]}\right)$ and other Galician rivers $\left(0.001-0.08 \mathrm{nM}^{[51,52]}\right)$ or even three times higher than those found for pristine rivers $\left(0.05 \mathrm{nM}^{[55]}\right)$.

Nickel average values were 12.19, 15.36 and $24.15 \mathrm{nM}$ for the Sor, Mera and Landro Rivers (Fig. 4). These values were close to 
background limits for world rivers $\left(13.6 \mathrm{nM}^{[8]}\right)$. Moreover, Ni concentrations in these rivers were 3-4 times higher than those found in pristine rivers $\left(4.4 \mathrm{nM}^{[55]}\right)$ but in the same range as other Galician rivers $\left(2.0-13.8 \mathrm{nM}^{[51,52]}\right)$. An increase in the concentrations of nickel was observed over the twentieth century because it is considered one of the proxies of the anthropogenic influence in natural systems. In this way, although Ni concentrations in these rivers are low, point diffuse sources may increase their concentrations.

Cobalt average concentrations were similar between the Sor and Landro Rivers (4.91 and 4.49 nM), whereas for the Mera River the average concentration was low $(1.85 \mathrm{nM})$. The Co world average value concentration was $2.51 \mathrm{nM},{ }^{[8]}$ however, this value could also be lower in non-polluted systems. In some Galician rivers background values range between 1.2 and $9.0 \mathrm{nM},{ }^{[51,52]}$ indicating the absence of human polluted activities.

In the Mera River, $\mathrm{Cu}$ concentrations are higher $(1.15-8.88 \mathrm{nM})$ than those reported for the Sor and Landro, averaging 1.35 and $1.25 \mathrm{nM}$ (Fig. 4). In terms of concentrations determined, dissolved $\mathrm{Cu}$ in these major freshwater inputs was found to be within typical values for uncontaminated river waters in the same area ${ }^{[20,23,51,52,63]}(1.8-10.5 \mathrm{nM})$. Moreover, $\mathrm{Cu}$ concentrations in these rivers are lower than those found in the pristine rivers. ${ }^{[55]}$ Although various sources can contribute to the input of copper to rivers (e.g. industrial and domestic wastewaters or agricultural activities), ${ }^{[2]}$ the high $\mathrm{Cu}$ dissolved concentrations in the Mera River in comparison with the other studied rivers may be explained by calcopirite mining areas localised in this watershed ${ }^{[58]}$ (Fig. 1).

In general, dissolved element concentrations in the major freshwater inputs to the Northern Galician Rias were found to be within typical values for uncontaminated pristine rivers. Moreover, in the dissolved load, the preferential dissolution of the different types of rocks and minerals present may be considered as the main factor that causes large variations in major and minor element abundances in rivers. The composition of the dissolved load of the studied rivers reflects the weathering of alumino-silicate rocks present in the watersheds of the Sor, Mera and Landro Rivers (Fig. 1).

\section{Calibration curves and annual fluxes}

The main process controlling the dynamics and variations of dissolved elements is the river discharge. It is assumed that concentration of various elements and species can be described as a function of stream discharge. In this way, power-law CQ calibration equations to predict the daily discharge fluxes were used (Table 2). The power-law functions were used to calculate the total annual fluxes. Concentration-flux relationships are often described using power-law equations. ${ }^{[64-66]}$

Dissolved nutrient concentrations decreased exponentially with increasing river water flow, showing a conservative behaviour (Fig. 5, Table 2), with the exception of nitrate in the Sor River. As such, at low river discharge, nutrient concentrations were high. This pattern was also observed for DOC, As, Fe (Fig. 5), Mo and V (Table 2). This implies that for these elements the dilution is the main factor controlling their concentration, and biological factors are minor. ${ }^{[6]}$ If biogeochemical cycling, exchange with solid phases, changes in temperature or biological activity within the river system takes place, the temporal variations of these elements will not be conservative. In this case, hydrologic events control elemental concentrations, but quantitative linkages between these parameters and river discharge and other watershed characteristics have been poorly elucidated.

On the other hand, the dissolved concentration of $\mathrm{Al}, \mathrm{Cd}, \mathrm{Co}, \mathrm{Cu}, \mathrm{Mn}, \mathrm{Ni}$ (Fig. 5), $\mathrm{Pb}, \mathrm{U}$ and $\mathrm{Zn}$, increased with river discharge. This behaviour is common in some major elements, ${ }^{[8]}$ and it could be related to an increase in the concentration of SPM due to sediment resuspension associated with high river flow and subsequent desorption from SPM.

To better understand the influence of small pristine rivers and watersheds on the coastal areas of the Northern Galician Rias, it is important to estimate the amount of materials discharged. In this way, an estimation of the total annual amounts of the dissolved organic and inorganic chemical species was carried out for the rivers draining into the Northern Galician Rias (Table 3). The mean annual river water flux into the Northern Galician Rias observed in 2008 is ,610 Kt year ${ }^{-1}$ for the Sor River, $319 \mathrm{Kt}_{\text {year }}^{-1}$ for the Landro River, and $189 \mathrm{Kt}$ year $^{-1}$ for the Mera River. The annual fluxes estimated here were in the same order of magnitude for other rivers in the study area $^{[19,21-23]}$ (Table 3), except for human-altered rivers such as those found in the Ria of Ferrol. ${ }^{[20,67]}$ It is important also to note the higher contributions of DIN in comparison with other pristine rivers with higher flow (e.g. the Oitaben and L'erez) in the Galician area. However, for phosphate, silicate, $\mathrm{Cu}, \mathrm{Pb}$ and $\mathrm{Zn}$ annual fluxes are comparatively lower or in the same order of magnitude (DOC, $\mathrm{Cd}, \mathrm{Fe}$ ).

If considering the ratio between the annual flux and the ria area, results show that for DIN and silicate the ratio between flux and area is considerably higher for the Northern Galician Rias compared to the rias of Pontevedra, Vigo and Ferrol. DIN and silicate may also have a coastal fertilising effect and this fact supports the importance of freshwater fertilisation by pristine rivers in small rias. In the case of the Northern Galician Rias, it is important to emphasise that DIN or silicate supply per ria area is between 2-17 times higher than for the Ria of Vigo. In the case of DOC, the supply per ria area is 2-15 times higher than for the Ria of Vigo. Therefore, the increase in nutrient concentration in the innermost part of the northern rias of Galicia ${ }^{[68]}$ during conditions of non-upwelling and high floods could cause an increase in the marine primary production, as observed in other areas. ${ }^{[13]}$ However, even with a large nutrient load per unit area of a ria, the effect of these nutrient loads will also be a function of its residence time within the innermost ria ${ }^{[1]}$ if the nutrients are flushed rapidly through it.

Dissolved $\mathrm{Cu}$ values per area of ria are of similar magnitude for the Northern Galician Rias and the rias of Vigo and Pontevedra. Dissolved Fe influx per area in the Northern Galician Rias was 5-10 times higher than for the Ria of Vigo, indicating that micronutrient fertilisation of the rias by means of freshwater may be important.

\section{Concluding remarks}

Results presented in this study have shown that the most important freshwater inputs to these temperate rias (nutrients, dissolved trace metals and carbon) were within typical values for Galician and world-unpolluted rivers, reflecting the geo-chemical background 
values. Nutrient loads showed that these rivers were not influenced by human activity and do not lead to eutrophication. In this way, temporal variability of the nutrient fluxes throughout the year could play an important role in this Galician Ria system, which is not severely affected by marine nutrient inputs due to the upwelling.

Most of the papers published thus far have only presented a partial dataset of the chemical composition of river water. This comprehensive summary is of specific value to environmental researchers and managers who need information on the water chemistry and background levels of natural European rivers. It also provides useful information in the development of European and global initiatives for assessing anthropogenic inputs to estuarine, coastal and open-sea environments.

\section{Acknowledgments}

The authors sincerely thank the staff of INTERESANTE for their kind cooperation during the sampling. Authors also thank 'Xunta de Galicia' for laboratory facilities in Celeiro; 'Meteogalicia' for meteorological data and 'Aguas de Galicia' for river flow data; J. Lorenzo for the processing and analysis of chlorophyll samples and M. D. Doval for DOC analyses. This work is a contribution to the Spanish LOICZ program and was supported by the 'Spanish Ministry of Science and Technology' through the CICYT program (INTERESANTE project, ref. CTM2007-62546-C03/MAR). N. Ospina-Alvarez thanks the Spanish National Research Council (CSIC) for their financial support (JAE-Pre contract). The authors are grateful to two anonymous referees for their detailed and valuable comments. 


\section{References}

[1] D. B. Nedwell, L. F. Dong, A. Sage, G. J. C. Underwood, Variations of the nutrients loads to the mainland UK estuaries: Correlation with catchment areas, urbanization and coastal Eutrophication. Estuar. Coast. Shelf Sci. 2002, 54, 951. doi: 10.1006/ECSS.2001.0867

[2] P. H. Monbet, Dissolved and particulate fluxes of copper through the Morlaix River estuary (Brittany, France): mass balance in a small estuary with strong agricultural catchment. Mar. Pollut. Bull. 2004,48,78. doi:10.1016/ S0025-326X(03)00327-8

[3] M. Masson, J. Schäfer, G. Blanc, A. Pierre, Seasonal variations and annual fluxes of arsenic in the Garonne, Dordogne and Isle Rivers, France. Sci. Total Environ. 2007, 373, 196. doi: 10.1016/J.SCITO TENV.2006.10.039

[4] M. Meybeck, R. Helmer, The quality of rivers - from pristine stage to global pollution. Palaeogeogr. Palaeocl. 1989, 75, 283. doi: 10.1016/0031-0182(89)90191-0

[5] J. Zhang, W. W. Huang, Dissolved trace-metals in the Huanghethe most turbid large river in the world. Water Res. 1993, 27, 1. doi:10.1016/0043-1354(93)90188-N

[6] B. T. Hart, T. Hines, Trace elements in rivers, in Trace Elements in Natural Waters (Ed B Salbu) 1995, pp. 203-221 (CRC Press: Boca Raton, FL).

[7] F. Elbaz-Poulichet, P. Seyler, L. Maurice-Bourgoin, J. L. Guyot, C. Dupuy, Trace element geochemistry in the upper Amazon drainage basin (Bolivia). Chem. Geol. 1999, 157, 319. doi:10.1016/S0009-2541(99)00015-7

[8] J. Gaillardet, J. Viers, B. Dupre, Trace elements in river waters, in Treatise on Geochemistry Vol. 5 (Eds HD Holland, KK Turekian) 2005, pp. 225-272 (Elsevier: Amsterdam).

[9] M. Meybeck, Dissolved and suspended matter carried by rivers: composition, time and space variations and world balance, in Inter- actions between Sediments and Fresh Water (Eds $\mathrm{H}$. L. Golterman, W. Junk) 1977 pp. 25-32 (Springer: The Hague, the Netherlands).

[10] J. M. Martin, M. Meybeck, Elemental mass-balance of material carried by major world rivers. Mar. Chem. 1979, 7, 173. doi:10.1016/0304-4203(79)90039-2

[11] C. Neal, A. J. Robson, A summary of river water quality data collected within the Land-Ocean Interaction Study: core data for eastern UK rivers draining to the North Sea. Sci. Total Environ. 2000, 251-252, 585. doi:10.1016/ S0048-9697(00)00397-1

[12] M. Olías, C. R. Cánovas, J. M. Nieto, A. M. Sarmiento, Evaluation of the dissolved contaminant load transported by the Tinto and Odiel rivers (South West Spain). Appl. Geochem. 2006, 21, 1733. doi:10.1016/J.APGEOCHEM. 2006.05.009

[13] A. Aviles, F. X. Niell, The control of a small dam in nutrient inputs to a hypertrophic estuary in a Mediterranean climate. Water Air Soil Pollut. 2007, 180, 97. doi:10.1007/ S11270-006-9253-4

[14] S. Falco, L. F. Niencheski, M. Rodilla, I. Romero, J. G. del Rio, J. P. Sierra, C. Mosso, Nutrient flux and budget in the Ebro estuary. Estuar. Coast. Shelf Sci. 2010, 87, 92. doi:10.1016/ J.ECSS.2009.12.020

[15] F. J. Río-Barja, F. Rodríguez-Lestegás, Os Rlos Galegos 1992 (Consello da Cultura Galega: Santiago de Compostela, Spain).

[16] A. F. Ríos, M. A. Nombela, F. F. Perez, G. Rosón, F. Fraga, Calculation of runoff to an estuary Ria de Vigo. Sci. Mar. 1992, 56, 29.

[17] M. Perez-Arlucea, M. Filgueira, M. Freijido, G. Mendez, Parametros morfometricos e hidrologicos de las cuencas de drenaje y rios tributarios a la ria de Vigo. Estimacion de las variaciones anuales en las cargas en suspension y en disolución. Journal of Iberian Geology 2001, 26, 171.
[18] M. Perez-Arlucea, G. Mendez, F. Clemente, M. Nombela, B. Rubio, M. Filgueira, Hydrology, sediment yield, erosion and sedimentation rates in the estuarine environment of the Ria de Vigo, Galicia, Spain. J. Mar. Syst. 2005, 54, 209. doi: 10.1016/J.JMARSYS.2004.07.013

[19] J. Vergara, R. Prego, Estimación de los aportes fluviales de nitrato, fosfato y silicato hacia las rías gallegas, in Procesos biogeoquimicos en sistemas costeros hispano-lusos (Eds R. Prego, J. M. Fernández) 1997, pp. 33-40 (Consejo Superior de Investigaciones Científicas: Pontevedra, Spain).

[20] A. Cobelo-García, R. Prego, A. Labandeira, Land inputs of trace metals, major elements, particulate organic carbon and suspended solids to an industrial coastal bay of the NE Atlantic. Water Res. 2004, 38, 1753. doi:10.1016/J.WATRES. 2003.12.038

[21] J. Gago, X. A. Alvarez-Salgado, M. Nieto-Cid, S. Brea, S. Piedracoba, Continental inputs of C, N, P and Si species to the Ria de Vigo (NW Spain). Estuar. Coast. Shelf Sci. 2005, 65, 74. doi:10.1016/J.ECSS.2005.05.008

[22] A. V. Filgueiras, R. Prego, Biogeochemical fluxes of iron from rainwater, rivers and sewage to a Galician Ria (NW Iberian Peninsu- la). Natural versus anthropogenic contributions. Biogeochemistry 2007, 86, 319. doi:10.1007/ S10533-007-9163-6

[23] J. Santos-Echeandía, L. M. Laglera, R. Prego, C. M. G. van den Berg, Copper speciation in estuarine waters by forward and reverse titra- tions. Mar. Chem. 2008, 108, 148. doi:10.1016/ J.MARCHEM.2007.

[24] E. Torre-Enciso, Estado actual del conocimiento de las rias gallegas, in Homenaxe a R. Otero Pedrayo 1958, pp. 237250 (Editorial Galaxia: Vigo, Spain).

[25] I. Díez, A. Secilla, A. Santolaria, J. M. Gorostiaga, The north coast of Spain, in Seas at the Millennium: an Environmental Evaluation: 1. Regional chapters: Europe, The Americas and West Africa (Ed. C. Sheppard) 2000, pp. 135-150 (Pergamon: Amsterdam).

[26] I. Alvarez, N. Ospina-Alvarez, Y. Pazos, M. deCastro, P. Bernardez, M. J. Campos, J. L. Gomez-Gesteira, M. T. Alvarez-Ossorio, M. Varela, M. Gomez-Gesteira, R. Prego, A winter upwelling event in the Northern Galician Rias: frequency and oceanographic implica- tions. Estuar. Coast. Shelf Sci. 2009, 82, 573. doi:10.1016/J.ECSS.2009.02.023

[27] M. Gomez-Gesteira, C. Moreira, I. Alvarez, M. de Castro, Ekman transport along the Galician coast (northwest Spain) calculated from forecasted winds. J. Geophys. Res., C, Oceans 2006, 111, C10005. doi:10.1029/2005JC003331

[28] Augas de Galicia 2011 (Consellería de Medio Ambiente, Territorio e Infraestructuras: Xunta de Galicia, Spain). Available at http:// augasdegalicia.xunta.es//gl/7.2.htm [Verified 31 January 2013].

[29] A. Aminot, Dosage de l'oxygène dissous, in Manuel des Analysses Chimiques en Milieu Marin (Eds A. Aminot, M. Chaussepied) 1983, pp. 75-92 (CNEXO: Brest, France).

[30] J. Kobayashi, Silica in freshwater and estuaries, in Chemical Environ- ment in the Aquatic Habitat. Biosphere Programme Symposium, 10-16 October 1966, Amsterdam and Nieuwersluis (Eds H. L. Golterman, R. S. Clymo) 1966, pp. 41-55. (Koninklijke Nederlandse Akademie Van Wetenschappen: Amsterdam).

[31] H. P. Hansen, F. Koroleff, Determination of nutrients, in Methods of Seawater Analysis (Eds K Grasshoff, K Kremling, M Ehrhardt) 1999, pp. 159-226 (Wiley-VCH: Weinheim).

[32] J. Neveux, M. Panouse, Spectrofluorometric determination of chlorophylls and pheophytins. Arch. Hydrobiol. 1987, 109, 567.

[33] Protocols for the joint global ocean flux study (JGOFS) core measurements, Manuals and guides 191994 (SCOR, Scientific Comite of Oceanic Research). Available at http:// ijgofs.whoi.edu/ Publications/Report_Series/JGOFS_19.pdf 
[Verified 8 February 2013].

[34] X. A. Álvarez-Salgado, A. E. J. Miller, Simultaneous determination of dissolved organic carbon and total dissolved nitrogen in seawater by high temperature catalytic oxidation: conditions for precise shipboard measurements. Mar. Chem. 1998, 62, 325. doi:10.1016/S0304-4203 (98)00037-1

[35] R. Thomas, M. Meybeck, The use of particulate material, in Water quality assessments (Ed D Chapman), 1992, pp. 121170 (Chapman \& Hall: London).

[36] D. H. Loring, R. T. T. Rantala, Manual for the geochemical analyses of marine sediments and suspended particulate matter. Earth Sci. Rev. 1992, 32, 235. doi: 10.1016/0012-8252(92)90001-A

[37] C. Neal, C. J. Smith, H. A. JeVery, H. P. Jarvie, A. J. Robson, Trace element concentrations in the major rivers entering the Humber estuary, NE England. J. Hydrol. 1996, 182, 37. doi: 10.1016/0022-1694(95)02940-0

[38] K. Grasshoff, Filtration and storage, in Methods of Seawater Analysis (Eds K Grasshoff, K Kremling, M Ehrhardt) 1999, pp. 21-30 (Wiley- VCH: Weinheim).

[39] Standard methods for the examination of water and wastewater, 20th edn 1995 (American Public Health Association: Baltimore, MD).

[40] B. Quemerais, D. Cossa, B. Rondeau, T. T. Pham, P. Gagnon, B. Fortin, Sources and fluxes of mercury in the St Lawrence river. Environ. Sci. Technol. 1999, 33, 840. doi: 10.1021/ES980400A

[41] M. Meybeck, G. Friedrich, R. Thomas, D. Chapman, Rivers, in Water Quality Assessments (Ed. D. Chapman) 1992 pp. 239-315 (Chapman \& Hall: London).

[42] B. W. Webb, J. M. Phillips, D. E. Walling, I. G. Littlewood, C. D.Watts, G. J. L. Leeks, Load estimation methodologies for British rivers and their relevance to the LOIS RACS(R) programme. Sci. Total Environ. 1997, 194-195, 379. doi: 10.1016/S0048-9697(96)05377-6

[43] B. W. Webb, J. M. Phillips, D. E. Walling, A new approach to deriving 'best-estimate' chemical fluxes for rivers draining the LOIS study area. Sci. Total Environ. 2000, 251-252, 45. doi:10.1016/S0048-9697 (00)00413-7

[44] R. Quilbe, A. N. Rousseau, M. Duchemin, A. Poulin, G. Gangbazo, J. P. Villeneuve, Selecting a calculation method to estimate sediment and nutrient loads in streams: application to the Beaurivage River (Quebec, Canada). J. Hydrol. 2006, 326, 295. doi:10.1016/J.JHY DROL.2005.11.008

[45] P. J. Johnes, Uncertainties in annual riverine phosphorus load estima- tion: impact of load estimation methodology, sampling frequency, baseflow index and catchment population density. J. Hydrol. 2007, 332, 241. doi:10.1016/ J.JHYDROL.2006.07.006

[46] S. D. Preston, V. J. Bierman, S. E. Silliman, An evaluation of methods for the estimation of tributary mass loads. Water Resour. Res.1989,25, 1379. doi:10.1029/ WR025I006P01379

[47] O. Pazos, M. A. Nombela, F. Vilas, Continental contribution of suspended sediment to an estuary: Ria de Vigo. Sci. Mar. 2000, 64, 295.

[48] C. Neal, J. Hilton, A. J. Wade, M. Neal, H. Wickham, Chlorophylla in the rivers of eastern England. Sci. Total Environ. 2006, 365, 84. doi:10.1016/J.SCITOTENV.2006.02.039

[49] G. Esser, G. H. Kohlmaier, in Biogeochemistry of Major World Rivers (Eds E. T. Degens, S. Kempe, J. E. Richey) 1991, pp. 169-211 (Wiley: Chichester, UK).

[50] R. Prego, J. Vergara, Nutrient fluxes to the Bay of Biscay from Cantabrian rivers (Spain). Oceanol. Acta 1998, 21, 271. doi: 10.1016/ S0399-1784(98)80014-5

[51] R. Salminen (Ed.) Geochemical Atlas of Europe. Part 1: Background Information, Methodology and Maps 2005 (Geological Survey of Finland: Espoo). Available at http:// weppi.gtk.fi/publ/foregsatlas/ [Verified 8 February 2013].
[52] T. De Vos, W. Tarvainen (Eds) Geochemical Atlas of Europe. Part 2: Interpretation of Geochemical Maps, Additional Tables, Figures, Maps and Related Publications 2006 (Geological Survey of Finland: Espoo). Available at http:// weppi.gtk.fi/publ/foregsatlas/part2.php [Verified 31 January 2013].

[53] D. L. Correll, Phosphorus: A rate limiting nutrient in surface waters. Poult. Sci. 1999, 78, 674.

[54] R. Prego, R. Bao, R. Howland, The biogeochemical cycling of dissolved silicate in a Galician Ría. Ophelia 1995, 42, 301. doi:10.1080/00785326.1995.10431510

[55] C. Guieu, W. W. Huang, J. M. Martin, Y. Y. Yong, Outflow of trace metals into the Laptev Sea by the Lena River. Mar. Chem. 1996, 53, 255. doi:10.1016/0304-4203(95)00093-3

[56] W. Admiraal, G. M. J. Tubbing, L. Breebaart, Effects of phytoplank- ton on metal partitioning in the lower River Rhine. Water Res.1995,29,941. doi: 10.1016/0043-1354(94)00204-K

[57] W. S. Moore, Amazon and Mississippi River concentrations of uranium, thorium and radium isotopes. Earth Planet. Sci. Lett. 1967, 2, 231. doi:10.1016/0012-821X(67)90134-3

[58] Memoria y mapa minero-metalogenico de Galicia 1: 400000 1982 (Instituto Geológico y Minero de España, Dirección de recursos minerales, Servicio de Publicaciones del Ministerio de Industria y Energía: Madrid).

[59] A. M. Shiller, E. A. Boyle, Dissolved vanadium in rivers and estuaries. Earth Planet. Sci. Lett. 1987, 86, 214. doi: 10.1016/0012-821X(87)90222-6

[60] A. M. Shiller, L. J. Mao, Dissolved vanadium in rivers: effects of silicate weathering. Chem. Geol. 2000, 165, 13. doi 10.1016/S0009-2541(99)00160-6

[61] J. M. Martin, M. H. Cotte, M. Dai, W. W. Huang, A. J. Thomas, D. Cossa, J. Sanjuan, M. Bourlat, D. M. Thouar, Enrichment of trace elements in European coastal waters. Ocean Margin exchange (OMEX) - first annual report 1994 (Universite Libre de Bruxelles: Brussels).

[62] F. Guitián-Ojea, Atlas Geoquimico de Galicia 1992 (Dirección Xeral de Industria: Xunta de Galicia).

[63] R. Prego, A. Cobelo-Garcia, Twentieth century overview of heavy metals in the Galician Rias (NW Iberian Peninsula). Environ. Pollut. $2003,121,425$. doi 10.1016S0269-7491(02)00231-2

[64] R. M. Vogel, J. R. Stedinger, R. P. Hooper, Discharge indices for water quality loads. Water Resour. Res. 2003, 39, 1273. doi:10.1029/2002WR001872

[65] R. A. Wheatcroft, M. A. Goni, J. A. Hatten, G. B. Pasternack, J. A.Warrick, The role of effective discharge in the ocean delivery of particulate organic carbon by small, mountainous river systems. Limnol. Oceanogr. 2010, 55, 161. doi:10.4319/ LO.2010.55.1.0161

[66] L. Klonsky, RM vogel effective measures of 'effective' discharge.J. Geol. 2011, 119, 1. doi:10.1086/657258

[67] A. Cobelo-García, R. Prego, Heavy metal sedimentary record in a Galician Ria (NW Spain): background values and recent contamination. Mar. Pollut. Bull. 2003, 46, 1253. doi:10.1016/ S0025-326X(03)00168-1

[68] N. Ospina-Alvarez, R. Prego, I. Álvarez, M. deCastro, M. T. Alvarez-Ossorio, Y. Pazos, M. J. Campos, P. Bernárdez, C. García-Soto, M. Gó mez-Gesteira, M. Varela, Oceanographical patterns during a summer upwellingdownwelling event in the Northern Galician Rias. Comparison with the whole Ria system (NW of contamination. Mar. Pollut. Bull. 2003, 46, 1253. doi:10.1016/ S0025-326X(03)00168-1

[68] N. Ospina-Alvarez, R. Prego, I. Álvarez, M. deCastro, M. T. Alvarez-Ossorio, Y. Pazos, M. J. Campos, P. Bernárdez, C. García-Soto, M. Gómez-Gesteira, M. Varela,

Oceanographical patterns during a summer upwellingdownwelling event in the Northern Galician Rias. Comparison with the whole Ria system (NW of Iberian Peninsula). Cont. Shelf Res. 2010 


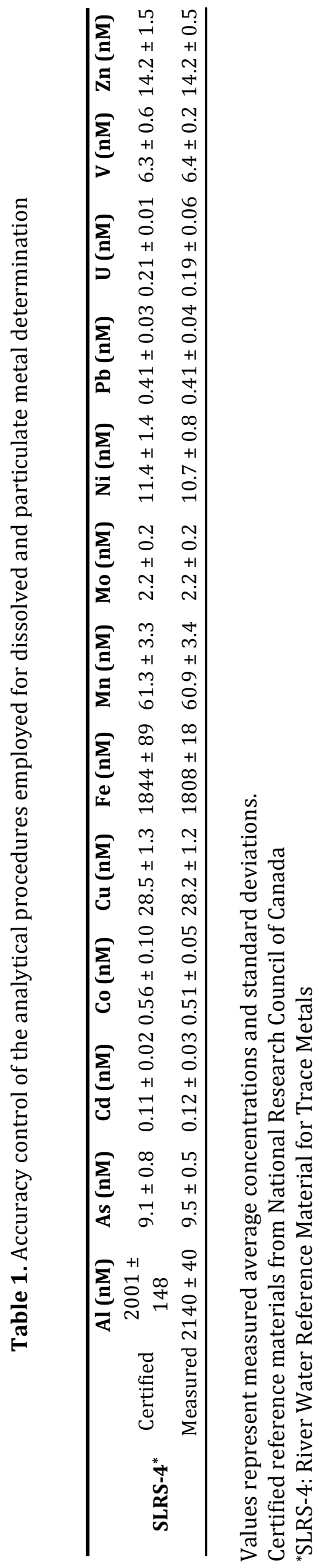


Table 2. Concentration-flow equations $\left(\mathrm{C}=\mathrm{a} \cdot \mathrm{Q}^{\mathrm{b}}\right)$ for the main rivers flowing into the Northern Galician Rias

\begin{tabular}{lccccccccc}
\hline River & \multicolumn{3}{c}{ Sor } & \multicolumn{3}{c}{ Mera } & \multicolumn{3}{c}{ Landro } \\
& $\mathrm{a}$ & $\mathrm{b}$ & $r$ & $\mathrm{a}$ & $\mathrm{b}$ & $r$ & $\mathrm{a}$ & $\mathrm{b}$ & $r$ \\
\hline Nitrate & 60 & -0.194 & 0.52 & 50 & 0.038 & 0.20 & 41 & 0.080 & 0.24 \\
Nitrite & 0.62 & -0.80 & 0.75 & 0.190 & -0.23 & 0.65 & 0.34 & -0.48 & 0.80 \\
Ammonium & 0.86 & -0.21 & 0.17 & 0.45 & -0.42 & 0.46 & 1.21 & -0.27 & 0.23 \\
Phosphate & 0.23 & -0.36 & 0.50 & 0.154 & -0.166 & 0.60 & 0.28 & -0.35 & 0.67 \\
Silicate & 133 & -0.165 & 0.81 & 192 & -0.144 & 0.86 & 197 & -0.173 & 0.73 \\
DOC & 225 & -0.24 & 0.63 & 122 & -0.088 & 0.46 & 187 & -0.066 & 0.22 \\
$\mathrm{Al}$ & 717 & 0.40 & 0.65 & 527 & 0.188 & 0.73 & 1590 & 0.25 & 0.60 \\
$\mathrm{As}$ & 16.2 & -0.61 & 0.78 & 4.27 & -0.178 & 0.85 & 3.41 & -0.27 & 0.74 \\
$\mathrm{Cd}$ & 0.0164 & 0.78 & 0.67 & 0.058 & 0.46 & 0.50 & 0.049 & 0.60 & 0.58 \\
$\mathrm{Co}$ & 0.45 & 0.75 & 0.78 & 1.56 & 0.115 & 0.37 & 0.54 & 0.82 & 0.75 \\
$\mathrm{Cu}$ & 0.23 & 0.57 & 0.78 & 2.71 & 0.28 & 0.73 & 0.48 & 0.40 & 0.59 \\
$\mathrm{Fe}$ & 1716 & -0.64 & 0.62 & 650 & -0.32 & 0.78 & 1790 & -0.45 & 0.67 \\
$\mathrm{Mn}$ & 13.2 & 0.75 & 0.78 & 51 & 0.077 & 0.29 & 67 & 0.51 & 0.79 \\
$\mathrm{Mo}$ & 1.36 & -0.59 & 0.68 & 0.67 & -0.27 & 0.27 & 0.56 & -0.63 & 0.75 \\
$\mathrm{Ni}$ & 2.55 & 0.58 & 0.95 & 11.8 & 0.164 & 0.59 & 6.71 & 0.56 & 0.95 \\
$\mathrm{~Pb}$ & 0.20 & 0.22 & 0.26 & 0.36 & 0.183 & 0.25 & 0.046 & 0.70 & 0.45 \\
$\mathrm{~V}$ & 23.0 & -0.65 & 0.63 & 12.1 & -0.32 & 0.82 & 17.1 & -0.51 & 0.61 \\
$\mathrm{U}$ & 0.0061 & 0.74 & 0.62 & 0.0082 & 0.82 & 0.87 & 0.182 & 0.38 & 0.82 \\
$\mathrm{Zn}$ & 11.1 & 0.37 & 0.75 & 23.7 & 0.101 & 0.41 & 20.0 & 0.23 & 0.47 \\
\hline
\end{tabular}

$\mathrm{Q}$ is the freshwater flow in $\mathrm{m}^{3} \cdot \mathrm{s}^{-1}$; $\mathrm{C}$ is the substance concentration in $\mathrm{nM}$ except for nutrients and organics $\mu \mathrm{M})$. $r$ corresponds to the regression coefficient. 
Table 3. Chemical contributions of the dissolved phase during 2008 by the rivers flowing into the Northern Galician Rias. Comparison with other coastal areas in the world

\begin{tabular}{|c|c|c|c|c|c|}
\hline & Sor & Mera & Landro & Other studies & unit \\
\hline $\mathrm{Qr}_{\mathrm{r}}$ & 610 & 189 & 319 & & $\mathrm{Kt} \cdot \mathrm{yr}^{-1}$ \\
\hline DIN & 274 & 149 & 234 & $158^{\mathrm{a}}$ & $t \cdot \mathrm{rr}^{-1}$ \\
\hline Phosphate & 1.36 & 0.61 & 1.13 & 7.89 a; $0,12,38^{c}$ & “ \\
\hline Silicate & 1319 & 726 & 1118 & 601a; 3910,1955, 4106c & “ \\
\hline DOC & 750 & 249 & 784 & $629 a$ & " \\
\hline $\mathrm{Al}$ & 50 & 4.3 & 28 & & “ \\
\hline As & 111 & 40 & 40 & & $\mathrm{~kg} \cdot \mathrm{yr}^{-1}$ \\
\hline $\mathrm{Cd}$ & 21.9 & 4.2 & 10.3 & $13^{\mathrm{f}^{*}}$ & " \\
\hline Co & 278 & 16 & 121 & & “ \\
\hline $\mathrm{Cu}$ & 74 & 67 & 31 & $514^{\mathrm{d}} ; 231 \mathrm{e} ; 3400^{\mathrm{f}}$ & “ \\
\hline $\mathrm{Fe}$ & 8.0 & 3.3 & 10.2 & $8.57^{b}$ & $\mathrm{t} \cdot \mathrm{yr}^{-1}$ \\
\hline $\mathrm{Mn}$ & 7035 & 647 & 5160 & & $\mathrm{~kg} \cdot \mathrm{yr}^{-1}$ \\
\hline Mo & 12.6 & 7.4 & 3.7 & & " \\
\hline $\mathrm{Ni}$ & 784 & 198 & 646 & & $"$ \\
\hline $\mathrm{Pb}$ & 31 & 11 & 15 & $1375^{\mathrm{f}}$ & “ \\
\hline V & 84 & 57 & 78 & & “ \\
\hline $\mathrm{U}$ & 14.6 & 3.8 & 40.9 & & “ \\
\hline $\mathrm{Zn}$ & 1675 & 391 & 660 & $4570^{\mathrm{f}}$ & “ \\
\hline
\end{tabular}

Italics represent those values calculated using average river flow and average concentration (Eq. 3) instead of using equations since the regression was poor.

aOitabén River Vigo Ria(Gago et al., 2005).

bOitabén River Vigo Ria (Filgueiras and Prego, 2007).

cMera, Sor and Landro rivers (Vergara and Prego, 1997).

dLérez River and sewage to the Pontevedra Ria (Cobelo-García and Prego, 2003).

eRivers to the Vigo ria (Santos-Echeandía et al., 2008).

fRivers to the Ferrol Ria (Cobelo-García et al., 2004). 


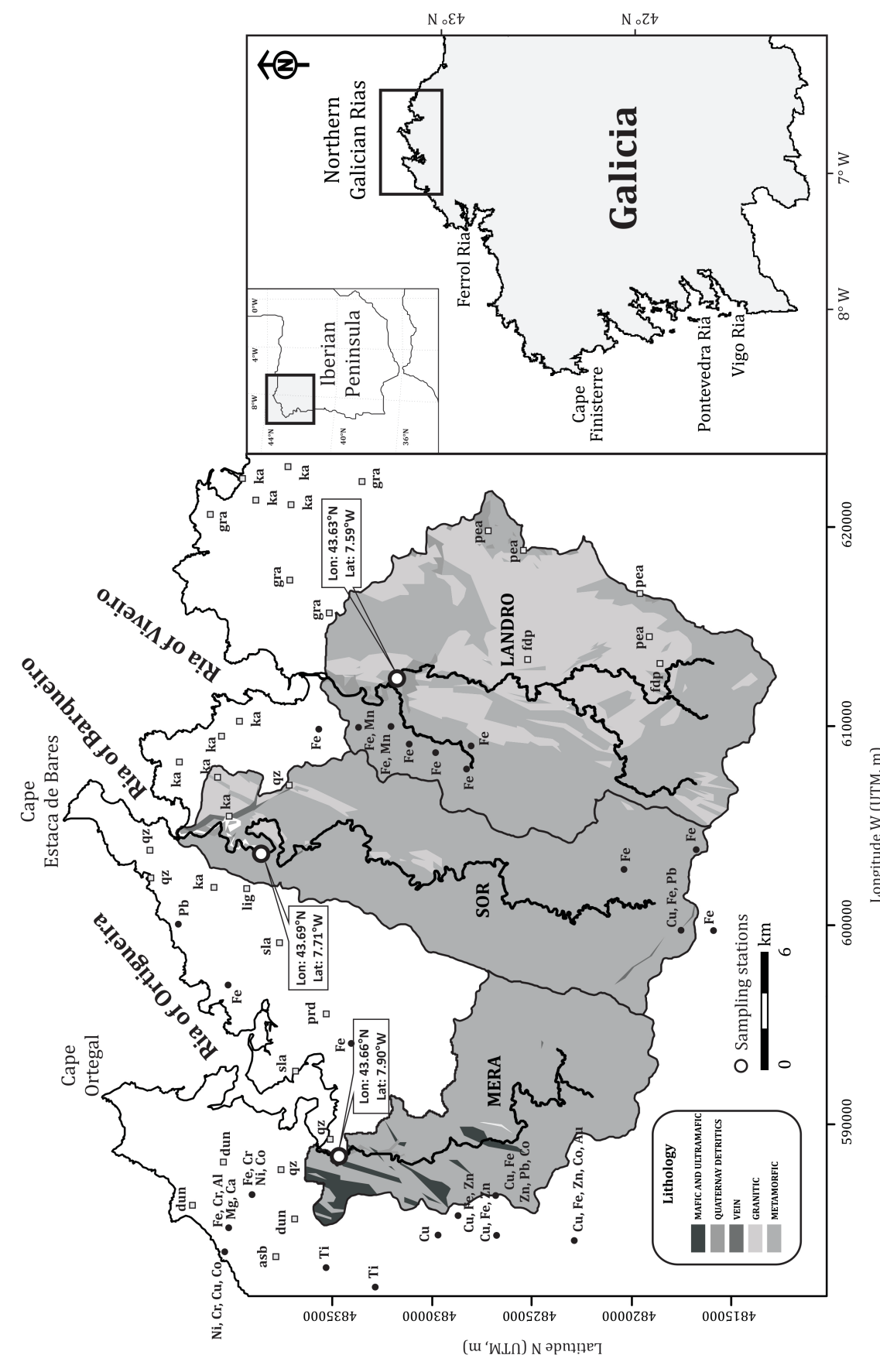

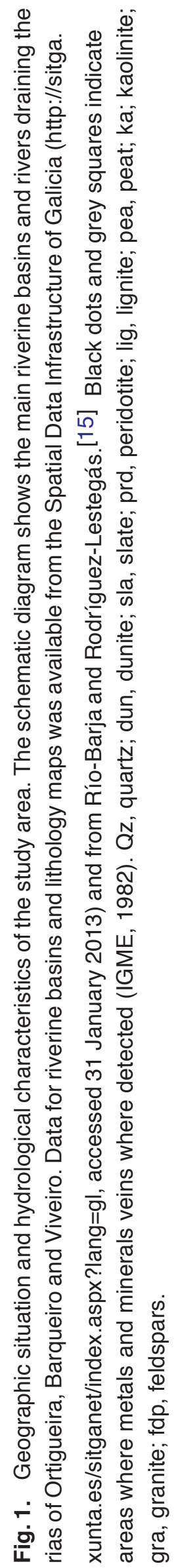




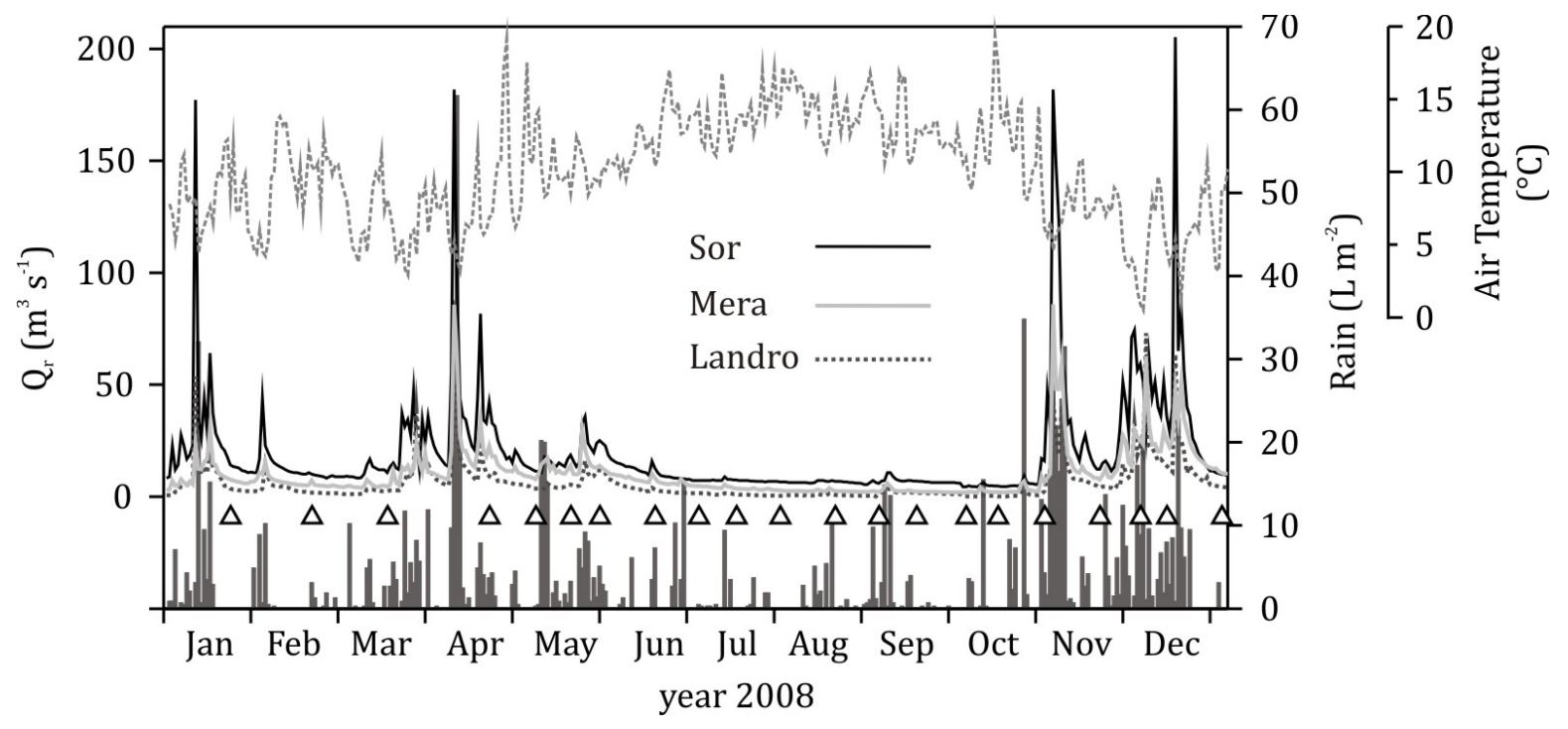

Fig. 2. Plot showing the river flow $\mathrm{Qr}$ (lines) of the main three rivers draining into the Northern Glacian Rias during 2008, the rain record (grey bars, $\mathrm{L} \mathrm{m}^{-2}$ ) and air temperature $(8 \mathrm{C}$ ) in the meteorological station of Penedo do Galo $(43.668 \mathrm{~N}, 7.568 \mathrm{~W})$ at Viveiro. Data available from the Regional Weather Forecast Agency (METEOGALICIA, http://www2. meteogalicia.es/galego/observacion/estacions/estacions. asp? idest=10104\&prov=Lugo\& red=102\&idprov=1\#, accessed 31 January 2013). 

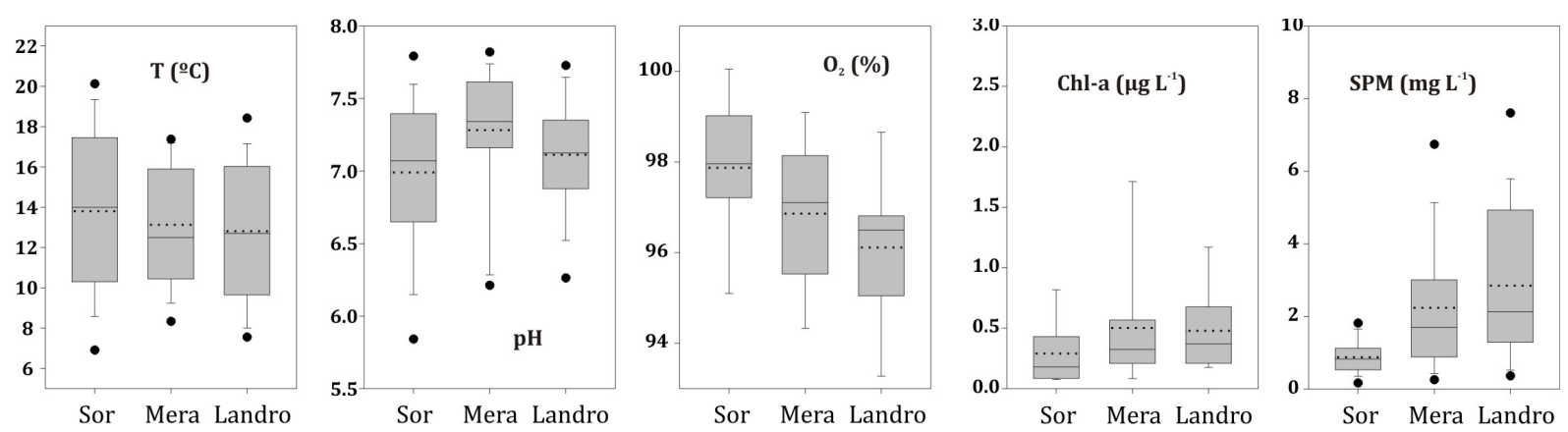

Fig. 3. Box-and-whisker plots of the master variables, (temperature $(\mathrm{T}), \mathrm{pH}$ and $\mathrm{O}_{2}$ ) and chlorophyll-a (Chl-a) and suspended particulate matter (SPM) concentrations determined from January 2008 to February 2009 in waters of the rivers draining into the area. The length of the box represents the interquartile range containing $50 \%$ of the values. The straight horizontal line inside the box indicates the median whereas the dotted horizontal line represents the mean. The whiskers are lines that extent from the box to the highest and lowest values excluding outliers and extremes. Outliers handling represent the 5 and 95 percentile. Outliers are defined as cases in which the values are between 1.5 and 3 times larger than the length of the box from its upper or lower border; those greater than three times are extremes. 

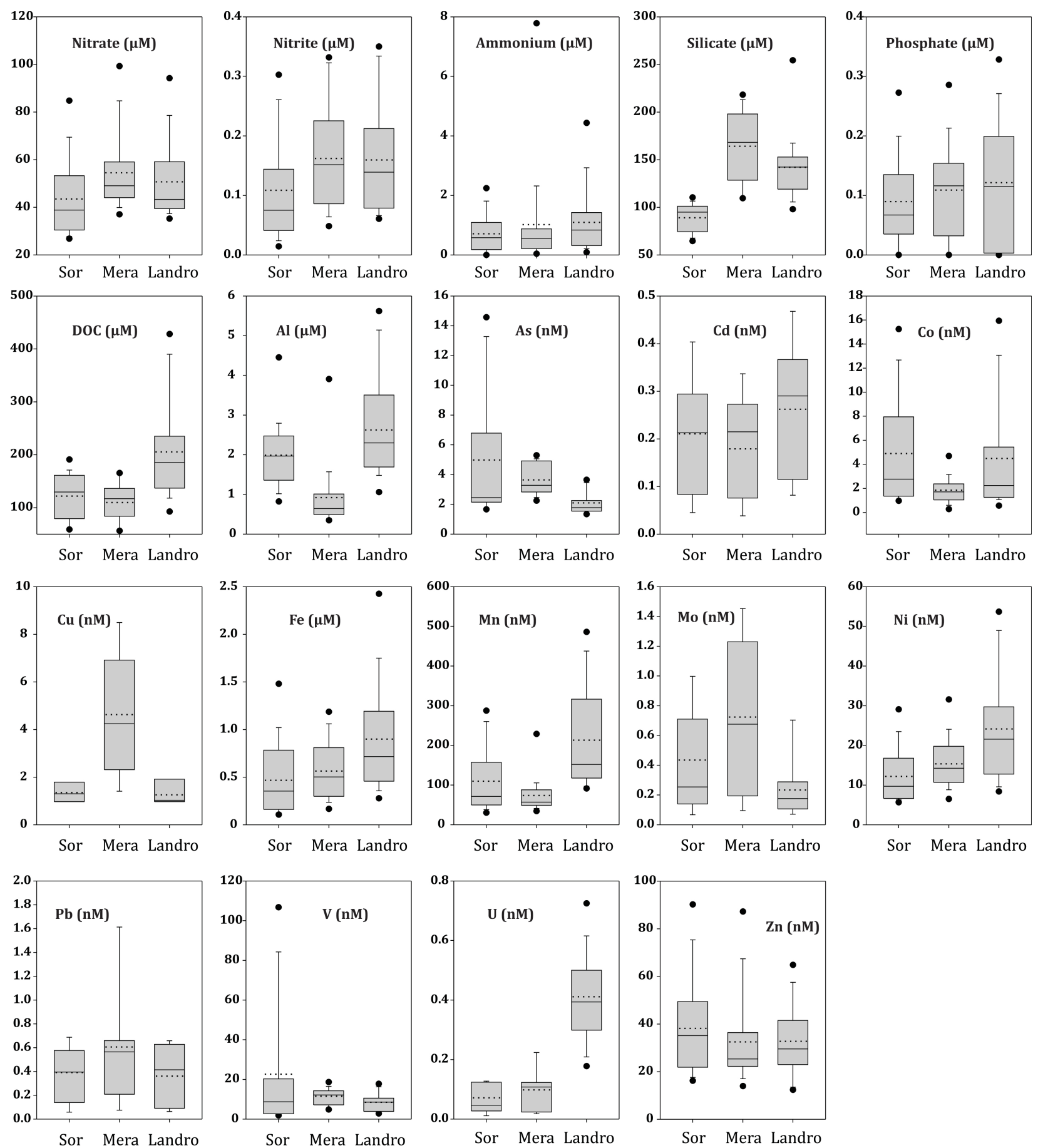

Fig. 4. Box-and-whisker plots with the concentration of several parameters in the dissolved phase determined from January 2008 to February 2009 in waters of the rivers draining the area. The length of the box represents the interquartile range containing $50 \%$ of the values. The straight horizontal line inside the box indicates the median whereas the dotted horizontal line represents the mean. The whiskers are lines that extent from the box to the highest and lowest values excluding outliers and extremes. Outliers handling represent the 5 and 95 percentile. Outliers are defined as cases in which the values are between 1.5 and 3 times larger than the length of the box from its upper or lower border; those greater than three times are extremes. (DOC, dissolved organic carbon.) 

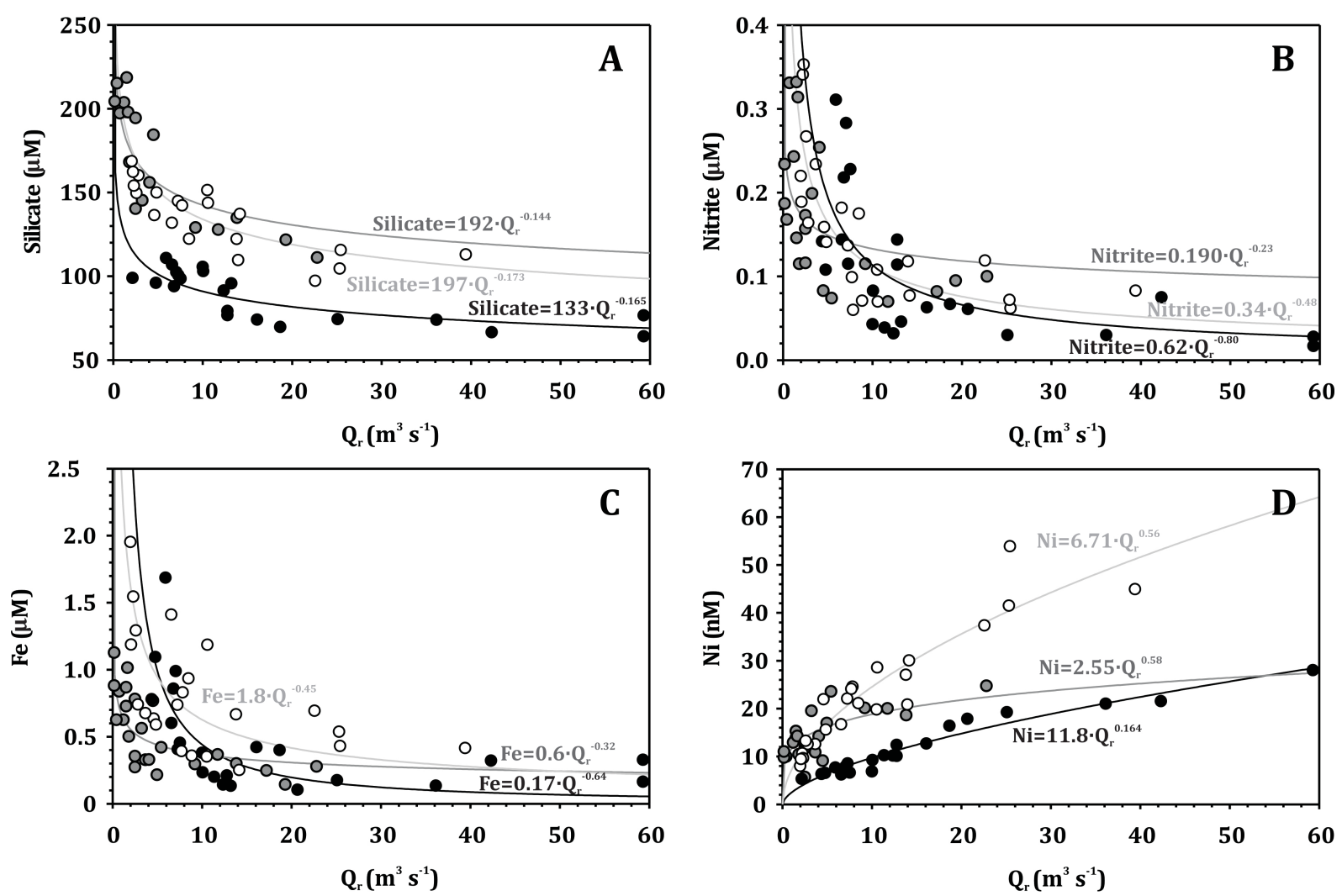

Fig. 5. Examples of concentration-flow equations $\left(C_{1 / 4}^{1 / a Q} Q^{b}\right)$ for the main rivers flowing into the Northern Galician Rias. $Q$ is the freshwater flow $\left(\mathrm{m}^{3} \mathrm{~s}^{-1}\right)$; $C$ is the substance concentration for metals $(\mathrm{nM})$ and nutrients $(\mathrm{mM})$. $r$ corresponds to the regression coefficient. 